\title{
ENERGY ATLAS
}

Future Concept Renewable Wilhelmsburg

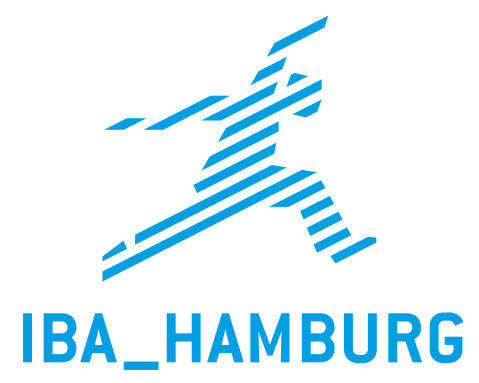




\section{ENERGY ATLAS}

Future Concept

Renewable Wilhelmsburg 